\title{
REINVENSI SYARIAH DALAM PERSPEKTIF TAFSIR KONTEMPORER AL-QUR'AN
}

\section{Muhamad Taufik Kustiawan}

Mahasiswa Pascasarjana UIN Sunan Kalijaga Yogyakarta awankusti09@gmail.com

\section{Supriyanto Agus Jibu}

Mahasiswa Pascasarjana UIN Sunan Kalijaga Yogyakarta jibusupriyanto@gmail.com

ABSTRACT: This paper is the writer's anxiety about the interpretation of the Koran regarding the understanding of sharia which is interpreted as Islamic law (God's law). This condition raises a variety of views among textual commentators (theocentric) and contemporary interpreters (anthropocentric) in expressing interpretations to provide an explanation of the meaning of sharia. This is because the meaning of sharia is often used as a legal basis and legitimacy for political-practical support for a number of conservative Islamic movements as part of carrying out the obligation to defend God. This view is contrary to contemporary Islamic thinkers such as Abdullahi Ahmed An-Na'im, Muhommad Hasim Kamali, Fazlur Rahman, Asghar Ali Engineer, Khaled M. Abou El-Fadl, and others. The Islamic thinkers above tend to understand sharia as a pathway to happiness and wisdom for all mankind. For contemporary Islamic thinkers, sharia is not interpreted as a strict and rigid law of God, but rather an Islamic legal methodology which has the characteristics of openness and antiauthoritarianism. So, if the communal meaning of sharia is interpreted in this way, it can certainly minimize the occurrence of conflicts of Islamic political power which often take the name of God, such as acts of terrorism which lead to acts of violence. Thus, to study the interpretation of the meaning of sharia, the author uses the grand figh theory initiated by Hamim Ilyas. This theory shows that in order to understand the principles of Islamic theology, it is necessary to understand figh, faith, ra'yu, context, the function of the faith, as a guide for studying the values of spirituality in the Islamic religious sciences. It can be said that this research is a qualitative research (library research) which emphasizes more on text sources. So that this research can contribute to providing an in-depth explanation of the 
interpretation of the Koran from the views of contemporary Islamic thinkers in interpreting sharia.

\section{Keywords: Sharia, Law, Al-Qur'an Tafsir}

ABSTRAK: Tulisan ini merupakan kegelisahan penulis terhadap tafsir Alquran tentang pemahaman syariah yang dimaknai sebagai hukum Islam (hukum Tuhan). Kondisi demikian memunculkan beragam pandangan di kalangan para mufasir tekstual (teosentris) dan mufasir kontemporer (antroposentris) dalam mengemukakan tafsir untuk memberikan penjelasan terhadap makna syariah. Sebab, makna syariah ini sering dijadikan landasan dasar hukum serta legitimasi untuk mendukung politik-praktis bagi sejumlah gerakan paham Islam konservatif sebagai bagian dari melaksanakan kewajiban membela Tuhan. Pandangan demikian bertentangan dengan para pemikir Islam kontemporer seperti Abdullahi Ahmed An-Na'im, Muhommad Hasim Kamali, Fazlur Rahman, Asghar Ali Engineer, Khaled M. Abou ElFadl, dan lain-lain. Pemikir Islam di atas cenderung memahami syariah sebagai jalan menuju kebahagiaan serta kebijaksanaan untuk semua umat manusia. Bagi kalangan pemikir Islam kontemporer, syariah bukanlah diartikan sebagai hukum Tuhan yang keras dan kaku, melainkan sebuah metodologi hukum Islam yang memiliki ciri keterbukaan dan antiotoritarianisme. Maka, seumpama makna syariah secara komunal ditafsirkan demikian tentu dapat meminimalisir terjadinya konflik kekuasaan politik Islam yang sering kali mengatas namakan Tuhan, seperti aksi terorisme yang menimbulkan aksi kekerasan. Sehingga, untuk mengkaji tafsir terhadap makna syariah, penulis menggunakan teori fikih akbar yang digagas oleh Hamim Ilyas. Teori tersebut menunjukan bahwa untuk memahami prinsip-prinsip teologi Islam, perlu memahami fikih, akidah, ra'yu, konteks, fungsi akidah, sebagai pedoman untuk mempelajari nilai-nilai spiritualitas dalam ilmu-ilmu agama Islam. Dapat dikatakan, bahwa penelitian ini merupakan penelitian kualitatif (library research) yang lebih menekankan sumber-sumber teks. Sehingga penelitian ini dapat berkontribusi memberikan penjelasan secara mendalam tentang tafsir Alquran dari pandangan pemikir Islam kontemporer dalam memaknai syariah.

\section{Kata kunci: Syariah, Hukum, Tafsir Alquran}

\section{PENDAHULUAN}

Pemaknaan syariah sering kali diterjemahkan sebagai "hukum Islam". Persoalan pemaknaan ini tampaknya menyebabkan perdebatan yang cukup panas di kalangan umat Islam. Belakangan 
diskursus ihwal pemaknaan "syariah" dapat disandarkan sebagai gerakan kebangkitan politik Islam di era modern. Perdebatan ini menjadi wacana serta kajian secara mendalam di negara-negara Barat. ${ }^{1}$ Sebab, fenomena ini juga sering menyebabkan umat Islam berselisih tentang epistemologi dan pemaknaan syariah pada dasarnya. Menurut Mohammad Daud Ali, syariah diartikan sama halnya dengan syariat. Secara harfiah syariah adalah konsep jalan menuju sumber (mata) air atau jalan lurus yang harus dilaksanakan atau dilalui oleh umat Islam. Syariah merupakan pedoman jalan hidup umat Muslim. Sebab syari'ah memuat ketetapan-ketetapan Allah Swt dan ketetapan Rasul-Nya, baik berupa larangan, seruhan, dan meliputi aspek hidup dan kehidupan manusia. ${ }^{2}$

Pemaknaan tersebut cukup senada seperti yang disampaikan Abdur Rauf, bahwa berpikir secara rasional merupakan upaya pembaharuan dalam menafsirkan ayat-ayat Alquran. Abdur Rauf memperjelas, bahwa hukum merupakan peraturan-peraturan yang terdiri dari ketentuan-ketentuan, suruhan dan larangan yang menimbulkan kewajiban dan hak. Pemaknaan ini tidak hanya melihat hukum melalui teks, namun juga melihat konteks dan pola ijtihad yang berkembang. ${ }^{3}$ Konsep terpenting dan paling komprehensif untuk menggambarkan Islam sebagai suatu fungsi adalah konsep syari'ah. Kata ini semula berarti jalur atau jalan menuju sumber air, atau sumber kehidupan. ${ }^{4}$ Kata kerja syara'a secara harfiah berarti menandai atau menggariskan jalan yang jelas menuju sumber air. Dalam konsep agama, sejak awal telah menunjukan jalan utama untuk kehidupan yang lebih baik. Hal ini berkaitan dengan nilai-nilai agama yang dinyatakan secara fungsional dan konkret untuk mengatur kehidupan manusia.

Kesinambungan syariah adalah Din (agama), yang secara harfiah ketundukan atau kepatuhan. Jika syariah merupakan penetapan jalan dan subjeknya adalah Tuhan, Din adalah kepatuhan terhadap jalan tersebut dan subjeknya adalah manusia. Syariah dan

1 Omid Safi dalam "Kata Pengantar", Membumikan Syariah: Pergulatan Mangaktualkan Islam, Terj. Miki Salman, (Bandung: Mizan, 2013), 1

2 Mohammad Daud Ali, Hukum Islam: Pengantar Ilmu Hukum Dan Tata Hukum Islam Di Indonesia, (Jakarta: Rajagrafindo Persada, 2002), 41

3 Abdul Rauf, Alquran Dan Ilmu Hukum, (Jakarta: Bulan Bintang, 1970), 21

4 Fazlur Rahman, Islam: Sejarah Pemikiran Dan Peradaban, (Bandung: Mizan, 2017), 
Din tampak sebagai dua hal yang sama, terutama jika melihat jalan dan muatannya. Karena itu, sebagaimana idiom Alquran, seseorang dapat menyebut syariah dan Din secara bergantian sejauh membahas kandungan agama. Tetapi, karena suasana Alquran adalah bentuk nasihat moral bagi manusia, maka umat Islam senantiasa perlu mengikuti dan mematuhi. Istilah Din atau Islam hampir sepadan, namun kata tersebut lebih sering muncul dalam Alquran ketimbang istilah syariah. Sehingga umat Islam memiliki tugas untuk menjelaskan syariah sebagai jalan atau titah Tuhan. ${ }^{5}$

Sejak awal, konsep syariah sudah memuat tujuan praktis yang jelas: di jalan yang ditetapkan Tuhan manusia mesti menjalani hidupnya untuk mewujudkan kehendak Ilahi. Abdullahi Ahmed An$\mathrm{Na}$ 'im menafsirkan makna syariah merupakan pintu atau koridor untuk menjadi seorang Muslim, meski tak menutup habis pintu-pintu pengetahuan manusia tentang Islam dan tentang pengalaman dalam merealisasikannya. Baik dalam hubungan dengan Islam ataupun syariah, kerangka acuan islami merupakan hasil dari apa yang disebut "agen manusia" dari kaum Mukmin atau sebuah sistem makna yang dibangun dari pengalaman dan refleksi introspektif manusia serta perkembangan yang lebih sistematis. ${ }^{6}$ Dasar pemikiran sebuah wacana Islam adalah setiap Muslim harus bertanggung jawab untuk mengetahui dan mengamalkan apa yang menjadi kewajiban agamanya. Prinsip dasar tanggung jawab seseorang yang tidak bisa dilepaskan atau didelegasikan ini adalah satu dari tema-tema Alquran yang terus diulang.

Namun, ketika umat Islam mencoba mengetahui dan mengamalkan apa yang diwajibkan syariah dalam situasi yang khusus, mereka lebih cenderung bertanya kepada ulama atau sufi yang mereka percaya dibanding mengacu langsung kepada Alquran dan Sunnah. Apakah yang dilakukan seseorang, orang alim atau sufi, merujuk kepada Alquran dan Sunnah serta-merta berlangsung melalui struktur dan metodologi yang sudah umum diterima? Ini biasanya terjadi dalam kerangka doktrin dan metodologi yang mapan dari sebuah mazhab tertentu, tetapi tidak pernah benar-benar dilakukan dengan cara yang segar dan orisinal, tanpa prakonsepsi

${ }^{5}$ Ibid... 146

6 Abdullahi Ahmed An-Na'im, Islam Dan Negara Sekuler: Menegosiasikan Masa Depan Syariah, Terj. Sri Murniati, (Bandung: Mizan, 2007), 27 
yang mengarahkan tentang bagaimana mengenali dan menafsirkan teks-teks Alquran dan Sunnah yang relevan. ${ }^{7}$ Syariah adalah inti pandangan-dunia Islam dan perangkat pengetahuan yang memberi peradaban Muslim ketentuan-ketentuan sikap yang tidak berubah dan juga sarana-sarana pokok untuk menyesuaikan diri dengan perubahan sosial. Secara teoritis, syariah meliputi seluruh aspek kehidupan manusia: pribadi, sosial, politik, dan intelektual. Dalam prakteknya, syariah memberi makna dan isi pada perilaku kaum Muslim dalam upaya-upaya keduniawian mereka.

Sebab pada umumnya, syariah dilukiskan sebagai 'hukum Islam.' Tetapi batasan-batasan syariah meluas melampaui cakrawala hukum yang terbatas. Syariah juga merupakan sistem etika dan nilai, sesuatu metodologi pragmatis yang dikembangkan untuk memecahkan masalah-masalah masa kini dan masa depan. Secara harfiah, syariah berarti jalan ke air - sumber segala kehidupan. Bagi peradaban Muslim, syariah melambangkan dahaga rohani dan duniawi yang tak terbatas dan tak pernah terpuaskan: masyarakat Muslim selalu mengusahakan pelaksanaan syariah yang semakin lama semakin baik dalam permasalahan masa kini dan masa depan mereka. Sifat islami peradaban Muslim diukur lewat keberhasilannya melaksanaan syariah: seberapa dekat (syariah) pada sumur air itu dalam kepatuhannya pada prinsip-prinsip hukum, etika dan metodologi syariah tersebut. Bentuk luar peradaban Muslim tergantung pada kondisi-kondisi ilmiah, teknologi, dan ekonomi dalam suatu masa tertentu. Bentuk-bentuk ini jelas berbeda dari masa ke masa dan melukiskan sifat dinamis pandangan dunia Islam. ${ }^{8}$

\section{HAKIKAT SYARIAH}

Mohammad Hashim Kamali, seorang pakar hukum Islam internasional menafsirkan secara harfiah makna syariah berarti titian menuju sumber air. Hal ini memperjelas, bahwa umat Islam senantiasa mengikuti jalan orang-orang beriman untuk mendapatkan petunjuk di dunia, dan untuk keselamatan di akhirat. Secara umum, syariah merujuk pada perintah, larangan, panduan, dan prinsip dari Tuhan untuk mengatur perilaku manusia. Panduan suci ini yang

7 Abdullahi Ahmed An-Na'im, Islam Dan Negara Sekuler: Menegosiasikan Masa Depan Syariah,.... 28-29

8 Ziauddin Sardar, Masa Depan Islam, Terj. Rahmani Astuti (Bandung: Pustaka, 1985), 107 
memungkinkan manusia meninggalkan dorongan hawa nafsu, yakni hasrat tanpa batas dan kecenderungan berbuat jahat; membimbing manusia menuju kebajikan dan kebenaran, serta menjadikan terhormat dan dipercaya sebagai khalifah. Oleh karena itu, manusia dipercaya mengemban tanggung jawab menegakkan keadilan sesuai dengan panduan syariah. ${ }^{9}$

Seperti yang dikemukakan sebelumnya, bahwa syariah adalah sebuah titian atau jalan pedoman agama. Sebab (syariah) tidak pernah terpisah, melainkan syariah bagian dari agama. Karena itu, jika agama adalah entitasnya, syariah hanyalah salah satu bagiannya. Sumber nilai-nilai syariah adalah bagian dari ajaran nilai-nilai Islam. Namun demikian, tidak sepaham dengan pandangan yang menggambarkan syariah sebagai "intisari pemikiran Islam, manifestasi paling tipikal jalan hidup islami, dan esensi Islam itu sendiri." Memang, tidak mungkin memisahkan syariah sepenuhnya dari agama, atau dari kepercayaan dan nilai-nilai dasar Islam. Namun, sebagaimana kesatuan dalam syariah dan agama Islam merupakan hal yang utama, dan di dalam salah satu aspek syariah terdapat yurisprudensi sipil yang mengakui adanya tingkatan perbedaan di dalam dogma dan struktur kepercayaan Islam. ${ }^{10}$

Sepanjang sejarah Islam, syariah belum pernah diabaikan, disalahpahami dan disalahtafsirkan sebanyak yang terjadi pada masa hidup kita sekarang ini. Kini, syariah banyak digunakan untuk membenarkan penindasan dan kelaliman, ketidakadilan dan penggulingan kekuasaan. Syariah telah diproyeksikan sebagai suatu perangkat hukum yang telah membatu dan hanya ada hubungannya sedikit atau malah tidak ada hubungannya sama sekali dengan zaman modern. Syariah telah dikemukakan sebagai suatu perangkat pengetahuan yang secara intelektual kosong, yang menjadi bagian dari sejarah masa silam dan bukannya masa kini atau masa mendatang. Semua ini telah merugikan kaum Muslim; dan telah menghalangi kebangkitan kembali Islam yang sejati dan kelahiran suatu tradisi Muslim masa kini. Banyak masalah yang dihadapi masyarakat Muslim masa kini yang muncul dari kenyataan bahwa syariah telah dibatasi menjadi bidang hukum saja.

${ }^{9}$ Hashim Kamali, Membumikan Syariah: Pergulatan Mangaktualkan Islam....19

${ }^{10} \mathrm{Ibid}, \ldots, 20$ 
Dengan demikian, syariah hanya menjadi pemikiran bagi para sarjana tradisional yang terpaku pada aturan-aturan hukum yang ditetapkan berratus-ratus tahun yang lalu oleh para ulama klasik, atau bagi para ahli hukum modern yang telah berusaha memahami syariah dengan sarana-sarana dari sistem-sistem hukum Barat. Baik nilai-nilai yang ingin dikemukakan syariah maupun soal-soal yang hendak dipecahkan sama-sama diabaikan. Terlebih tatkala syariah bukan hanya dipaksakan ke dalam kendala-kendala hukum yang sempit, melainkan dibatasi lebih ketat lagi ke dalam satu atau dua bagian dari persepsi-persepsi hukumnya. Sehingga, aspek-aspek syariah yang menyangkut kejahatan, hukuman, dan perilaku sosial terlahir nyata dalam tindakan dan pemikiran para sarjana tradisional dan masa modern. ${ }^{11}$

Dengan pembagian syariah seperti ini, dan mengabaikan keseluruhan cita-cita etikanya, berarti para sarjana dan ahli hukum Muslim telah menghancurkan sifat holistiknya yang sangat penting dan mengetengahkan dengan cara yang aneh sekali. Di satu pihak syariah menekankan belas kasihan, keseimbangan dan keselarasan, sedangkan di pihak lain para pendukung syariah masa kini menekankan hukuman-hukuman ekstrem tanpa mempertimbangkan lingkungan sosial maupun politik. Sementara syariah jelas-jelas menentang segala bentuk kelaliman, para pelestari syariah masa kini memaksakannya melalui sarana-sarana yang lalim. Sekalipun syariah mengajarkan keadilan politik dan sosial, dan kesamaan bagi semua orang di mata hukum, namun banyak orang yang mempraktekkannya berusaha untuk menjalankan aturan itu bagi kaum yang tertindas, serba kekurangan atau kelompok-kelompok minoritas dan orang-orang buangan dari negeri asing yang bagi mereka syariah tidak mempunyai makna. Sementara satu aspek syariah disembunyikan karena tidak sesuai dengan pemerintah oligarki atau adat-istiadat Barat, yang lain diberi tekanan berlebihan untuk menipu rakyat bahwa hukum syariah diberlakukan.

Maka, untuk menjelaskan esensi makna syariah perlu menafsirkan ayat-ayat Alquran yang menyinggung perihal syariah dengan menggunakan teori fikih akbar. Hal ini dilakukan untuk meninjau eksistensi dan konotasi penafsiran syariah secara kontekstual. Hamim Ilyas dalam buku Fikih Akbar: Prinsip-Prinsip

11 Ziauddin Sardar, Masa Depan Islam...67 
Teologis Islam Rahmatan Lil 'Alamin (2018) memberikan rekontruksi metodologis bahwa untuk memahami prinsip-prinsip teologi Islam, perlu memahami fikih, akidah, $r a^{\prime} y u$, konteks, fungsi akidah, sebagai pedoman untuk mempelajari nilai-nilai spiritualitas dalam ilmu-ilmu agama Islam. Hamim Ilyas membuat tipologi, untuk menafsirkan ayat-ayat Alquran dapat secara dialektik dan revolusioner. Tafsir dalam dua periode itu di kembangkan menggunakan paradigma. Paradigma adalah pandangan fundamental tentang pokok persoalan dari objek yang dikaji. Dalam studi tafsir, objek itu adalah Alquran. Sehingga paradigma tafsir itu adalah pandangan mendasar mengenai Alquran yang ditafsirkan, berkenaan dengan apa yang seharusnya dikaji dari kitab suci tersebut. ${ }^{12}$

Paradigma ini adalah pandangan fundamental bahwa Alquran kitab agama, dalam pengertian kitab tersebut memerlukan penjelasan dengan adanya penafsiran yang terus dikerjakan. Kecenderungan paradigmatik yang pertama adalah kompleksitas pembahasan dalam Alquran. Kecenderungan ini berupa pandangan fundamental bahwa Alquran merupakan sebuah kitab suci yang kompleks sehingga tafsir Alquran harus mampu menguraikan esensi kerumitannya. Tafsir harus mengupas banyak hal termasuk hal teknis, seperti pengucapan kata dalam Alquran.

Kedua, kecenderungan paradigmatik pada eksplanasi Alquran. Kecenderungan pandangan ini bahwa Alquran menjadi kitab suci yang mengikat bagi umat Islam, memerlukan penjelasan. Pihak yang memiliki otoritas untuk memberi penjelasan bukan hanya Nabi, sahabat, dan tabi'in saja. Generasi ulama yang datang sesudah mereka juga memiliki otoritas, meskipun ada keterbatasan kemampuan mereka dalam menjelaskan Alquran. Namun, hal itu harus ditoleransi, karena tanpa diberi penjelasan, Alquran bisa menjadi kitab suci yang tidak bermakna secara moral dan sosial. Ketiga, kecenderungan paradigmatik reduksionis. Kecenderungan ini bermakna bahwa Alquran merupakan dalil yang memiliki otoritas tertinggi yang harus dijadikan sumber legitimasi untuk mendukung mazhab supaya mempunyai kekuatan di kalangan umat. Paradigma tafsir reduksionis ini sering diterapkan secara luas dalam penafsiran

${ }^{12}$ Hamim Ilyas, Fikih Akbar: Prinsip-Prinsip Teologi Islam Rahmatan Lil'Alamin (Tanggerang Selatan: Alvabet, 2018), 67 
Alquran dan menghasilkan banyak karya tafsir yang bercorak partisan, baik dalam kalam, fikih, maupun politik. ${ }^{13}$

Sehingga dapat dikatakan bahwa esensi syariah yang termuat dalam ayat-ayat Alquran seperti apa yang disampaikan oleh Fazlur Rahman. Rahman menunjukan tafsir syariah dengan merujuk dalam Surah Asy-Syura: ayat 13.

"Dia Telah mensyari'atkan bagi kamu tentang agama apa yang Telah diwasiatkan-Nya kepada Nuh dan apa yang Telah kami wahyukan kepadamu dan apa yang Telah kami wasiatkan kepada Ibrahim, Musa dan Isa yaitu: Tegakkanlah agama [1340] dan janganlah kamu berpecah belah tentangnya. amat berat bagi orang-orang musyrik agama yang kamu seru mereka kepadanya. Allah menarik kepada agama itu orang yang dikehendaki-Nya dan memberi petunjuk kepada (agama)-Nya orang yang kembali (kepadaNya)."

Fazlur Rahman menafsirkan makna syariah tersebut dengan membagi tipologi menjadi dua perspektif pertimbangan: "pertimbangan religius dan pertimbangan historis". Faktor religius mengatur tentang perilaku orang mukmin, dan lebih banyak berbicara tentang Din, iman, dan Islam ketimbang syariah. Selama dorongan Alquran tetap kuat, seorang Muslim akan lebih berusaha mematuhi Tuhan, ia akan memandang usahanya itu untuk mencapai Din ketimbang mengklaimnya sebagai syariah. Karena hanya Tuhan yang mengetahui apakah pemahamannya itu adalah syariah. Selain itu, juga ada faktor sejarah, seperti sudah disebutkan bahwa fikih atau pemahaman waktu merupakan proses ketimbang bangunan pengetahuan, dan lebih pribadi, bebas dan subjektif, dibandingkan disiplin objektif. Mustahil seseorang mengklaim hasil pemikirannya sebagai kandungan syariah satu-satunya. Penjabaran syariah semestinya menjadi tugas seluruh umat dengan bimbingan para ulama. ${ }^{14}$ Mohammad Hashim Kamali menperjelas bahwa asal-usul syariah berkaitan dengan Surah Al-Jasiyah: ayat 18.

"Kemudian kami jadikan kamu berada di atas suatu syariat (peraturan) dari urusan (agama itu), Maka ikutilah syariat

\footnotetext{
${ }^{13}$ Hamim Ilyas, Fikih Akbar: Prinsip-Prinsip Teologi Islam Rahmatan Lil'Alamin...., 69

${ }^{14}$ Fazlur Rahman, Islam: Sejarah Pemikiran Dan Peradaban....,147
} 
itu dan janganlah kamu ikuti hawa nafsu orang-orang yang

tidak Mengetahui (QS 45: 18)".

Dalam catatan penjelasan ayat di atas, Abdullah Yusuf Ali mengatakan bahwa kata syari'atan dalam ayat ini paling baik diterjemahkan sebagai "jalan agama yang benar" yang lebih luas daripada ketentuan-ketentuan hukum yang sebagian besar diturunkan pada periode Madaniyah. Karena syariah sebagai suatu kitab undang-undang belum ada pada waktu ayat ini diturunkan, maka kata syariah di dalam Alquran merujuk pada makna literalnya tentang kepercayaan pada Islam (jalan yang ditunjukkan Tuhan) dan menghindari kekufuran. Maka, makna syariah adalah jalan menuju agama, ia pada pokoknya menyangkut nilai-nilai yang esensial bagi Islam dan merupakan cara terbaik untuk melindunginya. Islam terdiri di atas apa yang dikenal sebagai lima pilar (al-arkan alkhamsah), yakni kepercayaan pada Tuhan, ibadah shalat, puasa, haji, dan pemberian zakat kepada yang miskin. Karenanya, keimanan kepada Tuhan, cara menyembah-Nya dan ketaatan pada kelima pilar Islam merupakan perhatian utama syariah. Tata cara menyembah Tuhan dijelaskan dalam bagian syariah yang dikenal sebagai ibadat.

Kemudian persoalan keadilan, yang terkait dengan cara Tuhan Maha tinggi menginginkan perlakuan terhadap makhluk-makhluk ciptaannya, yang dijelaskan terutama di bawah judul umum muamalah. Salah satu bidang perhatian utama syariah adalah perlindungan dan penegakan lima hal esensial (al-dharuriyyat alkhamsah), yakni kehidupan, agama, hak milik, akal, dan keturunan. Sering dikatakan bahwa syariah dalam semua bagiannya berkenaan dengan cara-cara paling baik untuk melindungi nilai-nilai ini. Fikih adalah istilah padanan syariah dan keduanya sering digunakan bergantian: namun kedua kata ini tidak identik. Jika syariah disampaikan terutama wahyu yang terkandung dalam Alquran dan hadis sahih, maka fikih terutama merujuk pada coprus juris yang dikembangkan oleh berbagai mazhab, nama fuqaha dan hakim, penggunaan penelaran hukum (ijtihad) dan pemberian pendapat hukum (fatwa). ${ }^{15}$

Mohammad Hashim Kamali, Membumikan Syariah: Pergulatan Mangaktualkan 
Esensi Surah Al-Jasiyah: ayat 18 berkesinambungan dengan ayat 16 untuk menjelaskan dan memahami asbabul nuzul tentang makna syariah. Di dalam ayat 16 yang berbunyi:

"Sesungguhnya Telah kami berikan kepada Bani Israil Al Kitab (Taurat), kekuasaan dan kenabian dan kami berikan kepada mereka rezki-rezki yang baik dan kami lebihkan mereka atas bangsa-bangsa"

Sebelum menafsirkan teks Alquran, perlu memperhatikan prinsip-prinsip dasar seperti nilai-nilai wajib fundamental, pelindungan, universal, dan instruksional. Nilai-nilai ini tampak bersifat universal dan tidak terikat dengan konteks spesifik apapun. ${ }^{16}$ Sehingga nilai-nilai tersebut memunculkan munasabah yang di dalamnya memuat tauhid, ibadah, dan melaksanakan kebaikan terhadap sesama. Makna ayat di atas memang menyinggung tentang kekuasaan pada masa Bani Israil untuk menciptakan kemaslahatan sosial. Dari penjelasan dua ayat ini, konsep syariah mencerminkan proses pembangunan peradaban. Implementasi ini membuat reinvensi syariah begitu nyata setelah dari masa ke masa peradaban Islam bertujuan untuk menciptakan kemajuan dan keunggulan di berbagai sektor kehidupan.

Tentu hal ini memerlukan ijtihad, usaha keras dan gigih. Sehingga penalaran hukum secara independen dapat memberikan jawaban atas suatu masalah ketika Alquran dan Sunnah tidak dapat memberi jawaban. Seperti telah diuraikan, konsep ijma (konsensus) muncul sebagai hasil upaya percobaan ijtihad. ${ }^{17}$ Artinya ijtihad telah menuntut para perintis hukum pada kesimpulan bahwa para ulama harus memecahkan suatu masalah agar dapat dijadikan rujukan untuk memahami syariah secara komprehensif. Selain itu, sunnah juga dapat mendukung ijtihad yang juga bersumber dari syariah. Maka metode ijtihad ini sangat relevan untuk memahami syariah sebagai gagasan antroposentrisme.

\section{DOKTRIN DAN POLITISASI SYARIAH}

16 Abdullah Saeed, Al-Quran Abad 21: Tafsir Kontekstual, Terj. Ervan Nurtawab, (Bandung: Mizan, 2016), 152

17 Abdullahi Ahmed An-Na'im, Dekontruksi Syariah: Wacana Kebebasan Sipil, Hak Asasi Manusia, Dan Hubungan Internasional Dalam Islam, Terj. Ahmad Suaedy, (Yogyakarta: IRCiSoD, 2016), 45 
Di Timur Tengah, pergolakan arus politik agama masih menjadi basis pergerakan yang mempengaruhi struktur sosial. Pada kenyataanya, doktrin tersebut telah memainkan peran yang cukup efektif meskipun keyakinan tersebut bukan berperan tunggal. Ada indikasi perbedaan yang cukup menonjol di kalangan umat Muslim, bahwa doktrin tidak selalu memotivasi tindakan. Ada sejumlah asumsi atau alasan mengapa doktrin dan praktik kian rumit dan hampir tidak berkesinambungan. Alasannya yang masuk akal adalah doktrin dapat diumpamakan fiksi yang memiliki konseptual. Sebab di sini terdapat hierarki religius yang lebih mengedepankan kepentingan kelompok yang sering disebut "para pembela keimanan". Mereka (gerakan Islam konservatif) mengatakan bahwa prinsip-prinsip yang tertuang dalam kitab suci (Alquran) merupakan wahyu yang harus diajarkan menurut syariat Islam.

Dale F. Eickelman dan James Piscatori menyebut ada perbedaan penafsiran tentang syariah yang ditetapkan melalui wahyu. Perbedaan ini dapat disimpulkan bahwa rencana ilahiah dan pemahaman manusia belum tentu sama (berbeda) dan perbedaan itu terletak pada ruang kritik perenial. Sehingga bila itu terus terulang, maka keseluruhan politik dapat pula melegitimasi syariah sebagai bagian gerakan populisme yang semakin meluas. ${ }^{18}$ Pandangan demikian terus menerus menjadi ritual polemik di dunia Islam. Khalil Abdul Karim mengutip pendapat Muhammad Ahmad Khalafullah yang mengatakan sebenarnya tidak ada satu teks pun dalam syariat Islam yang mengatur soal-soal politik dan pemerintahan. ${ }^{19}$ Argumentasi tersebut jelas memberikan kritik terhadap gerakan Islam konservatif yang terus-menerus mempolitisasi makna syariah dengan politik ketatanegaraan. Hal itu apa dapat dikatakan bagian dari hikmah dari Tuhan untuk umat Muslim? Sebab, pada dasarnya manusia merupakan makhluk ciptaan Tuhan yang berakal, sehingga tugas utamanya adalah melaksanakan ijtihad secara mendalam. Cara demikan menjadi langkah progresif untuk mensyukuri nikmat yang telah Tuhan berikan. Bahwa manusia harus mengedepankan akal dan

${ }^{18}$ Dale F. Eickelman, JamePiscatori, Ekspresi Politik Muslim, Terj. Rofik Suhud, (Bandung: Mizan, 1998), 28

${ }^{19}$ Khalil Abdul Karim, Syari'ah: Sejarah, Perkelahian, Pemaknaan, Terj. Kamran As'ad (Yogyakarta: LKiS, 2003), 114 
logika untuk memahami makna tersirat yang terkandung di dalam Alquran.

Haedar Nashir mempertegas bahwa doktrin dan politisasi syariah di Indonesia telah menjadi alat propaganda dan kontestasi berebut kebenaran tafsir umat Islam. Pada tahun 1998, kontestasi ini menandai keterlibatan umat membangun jejaring gerakan populisme Islam yang diadobsi dari Timur Tengah. Gerakan sosial berbasis politik Islam ini kian tidak terbandung pasca lengsernya Soeharto di zaman Orde Baru. Mereka membangun partai politik sekaligus jejaring politik serta menyuarakan aspirasi syariat Islam melalui sektor pendidikan, keagamaan, dan panggung politik. ${ }^{20}$

Aksin Wijaya melihat fenomena sosial ini membagi kontestasi pemikiran Islam ini dengan membagi tipologi gerakan Islam di Indonesia: pemikiran Islam eksklusif, inklusif, dan pluralis. Situasi sosial-politik tersebut memperjelas bahwa gerakan Islam eksklusif cenderung semakin bebas dalam mengekspresikan gerakan dan membangun jaringan di Indonesia. Dampaknya gerakan ini sering menafsirkan Alquran secara kaku dan tekstualistik (teosentris) yang menyebabkan tafsir Alquran semakin absud untuk dipahami dalam konteks zaman modern. Sebab, mereka yang terjaring gerakan Islam eksklusif ini memang memiliki indikasi berafiliasi dengan gerakan Islam trannasional, seperti Wahhabi, Ikhwanul Muslimin, Hizbut Tahrir dan lain-lain. ${ }^{21}$

Vedi R. Hadiz menyebut fenomena yang terjadi saat ini pasca Reformasi berdampak pada meluasnya politik populisme Islam. ${ }^{22} \mathrm{Di}$ negara-negara maju, juga mengalami fenomena serupa yang disebabkan oleh ketidakpercayaan publik terhadap para pemangku kebijakan. Selain itu, masalah globalisasi juga telah menyeret rakyat awam terhadap isu-isu sosial yang diputuskan oleh pemerintah dengan tidak berpihak terhadap rakyat. Kebijakan-kebijakan yang berpihak pada pengusaha atau kelompok kapitalis turut menandai gerakan ini semakin masif dan mencari aspirasi. Dalam catatan

${ }^{20}$ Michael Buehler and Dani Muhtada, "Democratization and the Diffusion of Shari'a Law: Comparative Insights from Indonesia," South East Asia Research 24, no. 2 (2016), 261-282.

21 Aksin Wijaya, Kontestasi Merebut Kebenaran Islan Di Indonesia: Dari Berislam Secara Teologis Ke Berislam Secara Humanis, (Yogyakarta: IRCiSoD, 2019),62

${ }^{22}$ Vedi R Hadiz, Populisme Islam Di Indonesia Dan Timur Tengah, Terj. Ninus Andarnuswari, (Depok: LP3ES, 2019), 40 
sejarah penentuan konstitusi di Indonesia, telah terjadi perdebatan yang cukup menegangkan di kalangan para pendiri bangsa. Perdebatan tersebut dilatarbelakangi oleh pemilihan dasar negara yang dapat merangkul hak dan kewajiban setiap warga negara. Opini yang digiring terhadap demokrasi sebagai dasar konstitusi selalu dibawa ke dalam wacana sistem pemerintahan yang tidak islami akibat diadosi dari pemikiran barat. Hal ini membuat publik (gerakan Islam konservatif) selalu membenturkan eksistensi terhadap kandungan keadilan distributif yang tertuang di dalamnya.

Selain itu, Fred R. Von der Mehden juga mengemukakan penelitiannya dalam perkembangan kelompok Islam radikal di Malaysia dan Indonesia. Pada tahun 1984, di Indonesia sudah mengalami peningkatan dakwah para ustaz yang menekan tematema moralitas, pentingnya mengikuti hukum agama, dan kewajiban untuk memerangi mereka yang dianggap kafir. Kegiatan pengajian di kota-kota urban, dan kampus (masjid) yang diprofokatori oleh da'i lokal ini juga sangat berperan penting dalam memberikan doktin politisasi syariah. Gerakan ini sering kali memprotes serta ketidakterimaannya selalu diekspresikan dengan meneriakkan kalimah "Allahhu Akbar". ${ }^{23}$

Reaksi seperti ini tidak hanya terjadi di dalam satu negara, di negara-negara mayoritas Muslim justru sering berkonflik dan menimbulkan kekerasan. Hal demikian akibat melemahnya para pakar hukum dalam mengkaji hukum Islam klasik untuk dipadukan dengan perkembangan hukum modern. Khaled M. Abou El-Fadl mengatakan perlu adanya tindakan menekuni studi hukum Islam supaya dapat memadukan kedua sumber hukum tersebut (klasik dan modern). Bagi kelompok neoijtihad yang tergabung dari aktivis politik dan sosial tentu ingin membangun ulang hukum yang bersifat dogmatis dan simplistis. Di sinilah awal mulanya runtuhnya bangunan metodologi hukum Islam tradisional akibat lenyapnya struktur sosial serta lembaga tradisional. Sehingga, hukum lebih bersikap represif dan otoritarianisme. ${ }^{24}$

${ }^{23}$ Fred R. Von der Mehden,dkk, Politik Kebangkitan Islam: Keragaman Dan Kesatuan, ed. Shireen T. Hunter (Yogyakarta: Tiara Wacana, 2001), 254

${ }^{24}$ Khaled M. Abou El-Fadl, Atas Nama Tuhan: Dari Fikih Otoriter Ke Fikih Otoritatif, Terj. R. Cecep Lukman Yasin (Jakarta: Serambi, 2004), 249 
Maka, syariah harus ditafsirkan dapat memiliki relevansi terhadap keseimbangan berbagai konteks dan zaman, sehingga ada kaitannya hukum Islam dapat bergerak dinamis dalam pembentukkan makna. Sebab budaya hukum Islam sebenarnya dengan tegas mengatakan bahwa kehendak Tuhan dapat ditemukan melalui penyelidikan kumulatif secara terus-menerus. Literatur sumber-sumber hukum Islam semestinya harus tunduk terhadap berbagai intrepretasi dinamis. Namun, teks (sumber hukum Islam) ini harus terbuka dan tidak hanya sekedar menerima interpretasi majemuk, tetapi juga mendorong sebuah proses penelitian yang mendudukan teks pada posisi sentral. Dengan demikian akan melahirkan sebuah tradisi penggalian hukum secara komprehensif dan menghasilkan interpretasi baru. Teks tidak boleh tertutup supaya hasil menggalian hukum tidak terasa kaku dan otoritatif, sehingga pembaca (mufasir) harus melakukan pembacaan ulang di setiap zaman yang terus mengalami perubahan. ${ }^{25}$

Asghar Ali Engineer pernah melakukan pembacaan terhadap teks (kitab suci Alquran) secara komprehansif dan progresif. Ia melakukan pembacaan teks-teks hukum-hukum had yang termuat di dalam Alquran tidak secara tekstual melainkan dengan melakukan penggalian secara mendalam. Konsep hukuman hudud menurut Asghar Ali Engineer bukan suatu hukuman yang kontekstual dengan situasi sosial di dunia modern. Ia tidak menerima tapi memiliki dasar menolak dengan memperlihatkan prinsip-prinsip filosofis bahwa Nabi Muhammad tidak pernah melaksanakan hukuman yang keras. Sebab Nabi Muhammad tentunya juga mempertimbangkan aspekaspek keadilan distributif di masyarakat. Pelaksanaan hukuman harus memiliki latarbelakang filosofis sebelum dicantumkan atau diformulasikan ke dalam undang-undang. Kritik Asghar Ali Engineer terhadap konsep hudud merupakan langkah berani melalui pendekatan sejarah dan sosial. Konsep ini dapat diterima ketika dalam suatu tatanan masyarakat menganut sistem pemberlakuan syariat Islam, namun sistem tersebut tidak dapat diberlakukan di negara sekuler atau negara yang berasaskan demokrasi.

Jasser Auda membagi tipologi hukum Islam dengan membedakan apa itu artinya syariah, fikih, dan fatwa. Meski pada dasarnya tipologi ini berkaitan tetapi pengertian ini juga masih

25 Ibid...., 212 
menjadi problem hukum Islam dalam hal pemaknaan. Hukum Islam tentunya dapat memuat keadilan, kasih sayang, perkembangan dan lain-lain. Jasser Auda menganalisis tiga komponen yang dijadikan akronim dari hukum Islam tersebut menggunakan kategorisasi, interkoneksi, dan integrasi antar disiplin keilmuan. Ia mengatakan hukum Islam bukanlah syariah yang diajarkan Rasulullah dalam kehidupannya sehari-hari. Hukum Islam juga bukan fikih yang memuat khazanah dari berbagai pendapat mazhab yang berkembang pasca-kenabian. Jasser Auda justru menekankan bahwa hukum Islam adalah fatwa, dengan catatan fatwa tersebut memuat nilai-nilai moral serta tidak disalahgunakan untuk kepentingan politik. Sehingga fatwa harus dikeluarkan berdasarkan sumber-sumber hukum autentik Islam yang menghasilkan menjaga keselamatan masyarakat dan menjaga nilai-nilai dasar hukum Islam seperti yang terkandung dalam maqasid syariah.

\section{KESIMPULAN}

Kontestasi pemaknaan syariah sering memicu ketegangan terhadap demokrasi. Hal ini dipengaruhi oleh misi politik gerakan Islam konservatif yang sering memicu konflik dan tindakan intoleransi. Panasnya isu politik populisme Islam sering kali membuat publik turut terpengaruh akibat asumsi-asumsi normatif dan tekstualistik. Fenomena memaknai syariah langsung merujuk menjadi persoalan hukum Islam yang keras dan dianggap sebagai normatifitas dan yurisprudensi Islam yang bersifat absolut. Padahal, ulama kontemporer seperti Abdullahi Ahmed An-Na'im, Muhommad Hasim Kamali, Fazlur Rahman, Asghar Ali Engineer, Khaled M. Abou El-Fadl lebih cenderung melihat konsep syariah dalam teks-teks Alquran sebagai metodologi pendekatan terhadap agama (Islam) agar dapat memperoleh jalan kebijaksanaan dalam tataran kehidupan sosial umat Islam. Persoalan sebenarnya lebih mengedepankan tindakan ijtihad yang lebih fleksibel dan pola pikir modernis untuk menunjukkan esensi syariah dalam teks-teks Alquran agar tidak disalahgunakan sebagai tindakan politis-agamis. Kegagalan dalam menafsirkan makna syariah dapat memberikan justifikasi bahwa syariah langsung berkaitan dengan hal-hal yang tidak dapat dirasionalisasikan seperti kata normatif yang cenderung lebih tektualis ketimbang menunjukan konotasi yang kontekstual sesuai situasi zaman. 


\section{DAFTAR PUSTAKA}

Ahmed An-Na'im, Abdullahi. Dekontruksi Syariah: Wacana Kebebasan Sipil, Hak Asasi Manusia, Dan Hubungan Internasional Dalam Islam. Terj. Ahmad Suaedy. Yogyakarta: IRCiSoD, 2016.

- - - Islam Dan Negara Sekuler: Menegosiasikan Masa Depan Syariah. Terj. Sri Murniati. Bandung: Mizan, 2007.

Buehler, Michael, and Dani Muhtada. "Democratization and the Diffusion of Shari'a Law: Comparative Insights from Indonesia." South East Asia Research 24, no. 2 (2016): 261-282.

Daud Ali, Mohammad. Hukum Islam: Pengantar Ilmu Hukum Dan Tata Hukum Islam Di Indonesia. Jakarta: Rajagrafindo Persada, 2002.

Eickelman, Dale F, Piscatori, James. Ekspresi Politik Muslim. Terj. Rofik Suhud. Bandung: Mizan, 1998.

El-Fadl, Khaled M. Abou. Atas Nama Tuhan: Dari Fikih Otoriter Ke Fikih Otoritatif. Terj. R. Cecep Lukman Yasin. Jakarta: Serambi, 2004.

Hadiz, Vedi R. Populisme Islam Di Indonesia Dan Timur Tengah. Terj. Ninus Andarnuswari. Depok: LP3ES, 2019.

Hashim Kamali, Mohammad. Membumikan Syariah: Pergulatan Mangaktualkan Islam. Terj. Miki Salman. Bandung: Mizan, 2013.

Ilyas, Hamim. Fikih Akbar: Prinsip-Prinsip Teologi Islam Rahmatan Lil'Alamin. Tanggerang Selatan: Alvabet, 2018.

Karim, Khalil Abdul. Syari'ah: Sejarah, Perkelahian, Pemaknaan. Terj. Kamran As'ad. Yogyakarta: LKiS, 2003.

Mehden, Fred R. Von der. Politik Kebangkitan Islam: Keragaman Dan Kesatuan. Edited by Shireen T. Hunter. Yogyakarta: Tiara Wacana, 2001.

Nashir, Haedar. Islam Syariat: Reproduksi Salafiyah Ideologis Di Indonesia. Bandung: Mizan, 2013.

Rahman, Fazlur. Islam: Sejarah Pemikiran Dan Peradaban. Bandung: Mizan, 2017. 
Rauf, Abdul. Alquran Dan Ilmu Hukum. Jakarta: Bulan Bintang, 1970.

Saeed, Abdullah. Al-Quran Abad 21: Tafsir Kontekstual. Terj. Ervan Nurtawab. Bandung: Mizan, 2016.

Sardar, Ziauddin. Masa Depan Islam. Terj. Rahmani Astuti. Bandung: Pustaka, 1985.

Wijaya, Aksin. Kontestasi Merebut Kebenaran Islan Di Indonesia: Dari Berislam Secara Teologis Ke Berislam Secara Humanis. Yogyakarta: IRCiSoD, 2019. 